\title{
Circadian Rhythm of Glucose Tolerance in Laboratory Mice
}

\author{
N.W. NOWELL \\ Department of Zoology, University of Hull, Yorkshire, England
}

Received: August 29, 1969

\begin{abstract}
Summary. Mice on a regular light-dark cycle were subjected, at $08.00,13.00,20.00$ and $01.00 \mathrm{~h}$, to the following assay procedures: Glucose tolerance in both fed and fasted animals; insulin sensitivity in fed animals; liver glycogen assay in fed animals. Feeding activity was also measured at these times. Glucose tolerance did not vary in the fasted groups but showed a single large increase with its peak at $01.00 \mathrm{~h}$ in the fed groups. Insulin sensitivity showed lower values in the evening than at other times and the liver showed a pattern of glycogen deposition from 13.00 to $01.00 \mathrm{~h}$ and release from 01.00 to $13.00 \mathrm{~h}$. Mid-morning and mid-night peaks of feeding activity were observed. It is suggested that the high glucose tolerance at $01.00 \mathrm{~h}$ is due to the coincidence of high glycogen deposition and high insulin activity at this time and that the insulin sensitivity changes are closely related to the liver glycogen cycle. - The effects of handling stress on grouped animals are reported and clearly indicate both the hyperglycaemic and the insulin-antagonistic responses to this stress.
\end{abstract}

Rythme circadien de la tolérance au glucose chez des souris de laboratoire

Résumé. Chez des souris soumises à un cycle lumièreobscurité régulier, on a procédé à $8 \mathrm{~h}, 13 \mathrm{~h}, 20 \mathrm{~h}$ et $1 \mathrm{~h}$ aux tests suivants: tolérance au glucose à la fois chez les animaux noưris et à jeun; sensibilité à l'insuline chez les animaux nourris; dosage du glycogène hépatique chez les animaux nourris. L'activité alimentaire était également mesurée aux mêmes houres. La tolérance au glucose ne variait pas dans les groupes à jeun, mais dans les groupes nourris elle montrait une seule augmentation importante ayant son pic à $1 \mathrm{~h}$. La sensibilité à l'insuline montrait des valeurs plus basses le soir qu'aux autres moments et le foie stockait le glycogène de $13 \mathrm{~h}$ à $1 \mathrm{~h}$ et le libérait de $1 \mathrm{~h}$ à $13 \mathrm{~h}$. On a observé des pics d'activité alimentaire au milieu de la journée et au milieu de la nuit. On suggère que la haute tolérance au glucose à $1 \mathrm{~h}$ est due à la coînci- dence du dépôt élevé de glycogène et de la forte activité insulinique à ce moment et que les changements dans la sensibilité à l'insuline sont on relation étroite avec le cycle du glycogène hépatique. - Les effets du stress de manipulation sur les animaux groupés sont rapportés et montrent clairement les réponses hyperglycémiques et antagonistes de l'insulino à ce stress.

Der Tagesrhythmus der Glucose-Toleranz bei Laboratoriumsmäusen

Zusammenfassung. Bei Mäusen wurden während eines regulären Hell-Dunkel-Cyclus um 8, 13, 20 und 1 Uhr die folgenden Untersuchungen vorgenommen: Glucose-Toleranz beim nüchternen und gefütterten Tier; Insulinempfindlichkeit bei gefütterten Tieren; LeberglykogenMessung bei gefütterten Tieren. Die Intensität der Nahrungsaufnahme wurde ebenfalls zu diesen Zeiten bestimmt. Die Glucose-Toleranz variierte bei den gefasteten Gruppen nicht, zeigte jedoch einen einzigen starken Anstieg mit einem Gipfel um 1 Uhr bei den gefütterten Gruppen. Für die Insulinempfindlichkeit ergaben sich abends niedrigere Werte als zu den anderen Zeiten und die Leber zeigte von 13 bis 1 Uhr das Bild der Glykogeneinlagerung und von 1 bis $13 \mathrm{Uhr}$ das Bild der Glykogenfreisetzung. In der Mitte des Vormittags und um Mitternacht fanden sich Spitzen der Nahrungsaufnahme. Es wird die Hypothese aufgestellt, daß die verbesserte Glucose-Toleranz um 1 Uhr auf das Zusammentreffen einer hohen Glykogeneinlagerung und einer hohen Insulinaktivität um diese Zeit beruht und daß die Änderungen der Insulinempfindlichkeit eng mit dom Leberglykogen-Cyclus zusammenhängen. - Die Stress-Auswirkungen beim Anfassen der gruppierten Tiere werden geschildert. Sie demonstrieren klar die hyperglykämisierenden und die insulin-antagonistischen Auswirkungen dieser Belastung.

Key-words: Circadian rhythm, glucose tolerance, insulin sensitivity, liver glycogen of mouse.

\section{Introduction}

Recent studies involving glucose tolerance and insulin sensitivity in the laboratory rat and golden hamster $[10,8]$ have suggested the possibility of a circadian variation in the capacity of these animals to deal with a sugar load. This possibility is supported by the demonstration of $24 \mathrm{~h}$ periodicities in adrenocortical activity in the rat [4] and in the mouse [5]. Also Hellman and Hellerstrom [7] concluded, as a result of studies on nuclear size in the pancreatic islets of the rat, that a daily rhythm of insulin production exists in this animal.

The present paper describes the effects of glucose loads administered to mice at different times of the day. Other parameters which must influence the tolerance to glucose were also recorded throughout a
$24 \mathrm{~h}$ period. Thus, the sensitivity, as far as blood sugar is concerned, to an exogenous dose of insulin, the concentration of liver glycogen and the feeding activity were measured in order to relate these parameters to any changes in glucose tolerance.

\section{Materials and Methods}

Male albino mice weighing approximately $30 \mathrm{~g}$ were used. They were kept at a constant temperature of $21^{\circ} \mathrm{C}$., and fed on Oxoid Diet $41 \mathrm{~B}$ pellets and water ad libitum. Artificial lighting provided a $12 \mathrm{~h}$ light period from 08.00 to $20.00 \mathrm{~h}$ daily. The mice were housed in plastic cages in groups of 9 or 10 animals.

Glucose tolerance. This test followed the pattern of intravenous glucose tolerance tests used previously on 
rat and hamster [10]. The intravenous injection of glucose, as compared with its oral administration, results, within minutes, in a return of blood sugar to normal levels. It was considered that the absolute increase in blood sugar $10 \mathrm{~min}$ after a glucose load, when the tolerance curve is at its steepest, would provide a useful index of the animal's capacity to cope with this load. Immediately before the test was due to start a cage of mice was transferred to the operating room, with as little disturbance as possible, and the first animal for test was removed within $5 \mathrm{~min}$, anaesthetized with nembutal and given an intravenous dose of heparin $(50 \mathrm{U} / 100 \mathrm{~g})$. Two minutes later a control sample $(0.1 \mathrm{ml})$ of blood was withdrawn from the left jugular vein and the glucose load $(0.2 \mathrm{ml} / 100 \mathrm{~g}$ of $30 \%$ glucose) injected into the right jugular vein. The second sample was removed precisely $10 \mathrm{~min}$ later. Successive mice were removed from the cage at intervals of approximately $8 \mathrm{~min}$.
Liver glycogen. Mice were anaesthetized with nembutal, their livers exposed and a section removed from the median lobe by means of a cork-borer. Sections were removed from exactly the same position so that their structure and weight varied very little. Approximately $100 \mathrm{mg}$ was removed, weighed accurately on a torsion balance and plunged immediately into hot potassium hydroxide. The glycogen content of these samples was assayed by the anthrone method.

Glucose tolerance and insulin sensitivity tests and liver glycogen assays were performed on groups of animals at the following times: $08.00-09.00 \mathrm{~h}$; $13.00-14.00 \mathrm{~h} ; 20.00-21.00 \mathrm{~h} ; 01.00-02.00 \mathrm{~h}$. In addition, a liver glycogen assay was performed at $16.00-17.00 \mathrm{~h}$ in order to position the minimum point of the concentration curve.

Feeding activity. A known weight of food was given at the beginning of the day's record, and the amount removed was calculated every two hours by deduction

Table 1. The blood sugar of fasted and fed mice in response to a glucose load

\begin{tabular}{|c|c|c|c|c|c|}
\hline & \multirow[b]{2}{*}{ Time of test } & \multirow[b]{2}{*}{$\begin{array}{l}\text { No. of } \\
\text { mice }\end{array}$} & \multicolumn{3}{|c|}{ Blood sugar - mg/100 ml } \\
\hline & & & $\begin{array}{l}\text { Control sample } \\
\text { (a) }\end{array}$ & $\begin{array}{l}10 \text { min } \\
\text { sample (b) }\end{array}$ & $\begin{array}{l}10 \text { min } \\
\text { increase } \\
\text { (b) - (a) }\end{array}$ \\
\hline Fasted & $\begin{array}{l}08.00-09.00 \\
13.00-14.00 \\
\mathbf{2} 0.00-\mathbf{2 1 . 0 0} \\
01.00-02.00\end{array}$ & $\begin{array}{l}9 \\
9 \\
9 \\
9\end{array}$ & $\begin{array}{l}62 \pm 6.5^{\mathrm{a}} \\
53 \pm 4.8 \\
64 \pm 3.4 \\
54 \pm 3.6\end{array}$ & $\begin{array}{l}171 \pm 9.1^{\mathrm{a}} \\
169 \pm 4.8 \\
184 \pm 6.6 \\
174 \pm 9.3\end{array}$ & $\begin{array}{l}109 \pm 4.5^{\mathrm{a}} \\
116 \pm 5.4 \\
120 \pm 6.0 \\
120 \pm 7.5\end{array}$ \\
\hline Fed & $\begin{array}{l}08.00-09.00 \\
13.00-14.00 \\
20.00-21.00 \\
01.00-02.00\end{array}$ & $\begin{array}{l}9 \\
9 \\
9 \\
9\end{array}$ & $\begin{array}{l}115 \pm 7.3 \\
134 \pm 3.0 \\
105 \pm 6.0 \\
108 \pm 3.4\end{array}$ & $\begin{array}{l}215 \pm 10.8 \\
227 \pm 8.3 \\
199 \pm 8.0 \\
158 \pm 7.4\end{array}$ & $\begin{array}{r}100 \pm 5.0 \\
93 \pm 6.7 \\
94 \pm 5.2 \\
50 \pm 9.0\end{array}$ \\
\hline
\end{tabular}

a S.E.

Table 2. The blood sugar response to an intravenous dose of insulin (2U/100 g)

\begin{tabular}{llllll}
\hline \multirow{2}{*}{ Time of test } & $\begin{array}{l}\text { No. of } \\
\text { mice }\end{array}$ & $\begin{array}{l}\text { Blood sugar }-\mathrm{mg} / 100 \mathrm{ml} \\
\text { (a) }\end{array}$ & & sontrol sample $10 \mathrm{~min}$ \\
sample (b) & $\begin{array}{l}10 \mathrm{~min} \\
\text { decrease } \\
\text { (a) }-(\mathrm{b})\end{array}$ & $\begin{array}{l}10 \mathrm{~min} \\
\text { decrease } \\
\% \text { of control }\end{array}$ \\
\hline $08.00-09.00$ & 9 & $140 \pm 6.7^{\mathrm{a}}$ & $76 \pm 4.5^{\mathrm{a}}$ & $64 \pm 6.4^{\mathrm{a}}$ & $45.0 \pm 3.3^{\mathrm{a}}$ \\
$13.00-14.00$ & 9 & $156 \pm 8.9$ & $92 \pm 7.0$ & $64 \pm 4.1$ & $41.0 \pm 2.2$ \\
$20.00-21.00$ & 9 & $122 \pm 11.8$ & $81 \pm 9.5$ & $41 \pm 4.4$ & $34.4 \pm 3.1$ \\
$01.00-02.00$ & 9 & $119 \pm 9.1$ & $66 \pm 3.8$ & $53 \pm 8.2$ & $42.0 \pm 4.6$ \\
\hline
\end{tabular}

a S.E.

Glucose tolerance tests were performed on groups of mice which had been fed up to the time of the test, and also on groups which had been fasted for a period of $24 \mathrm{~h}$ before the test.

Insulin Sensitivity. This test was performed on animals which had been fed up to the time of the test and followed the pattern of the glucose tolerance test except that insulin ( $2 \mathrm{U} / 100 \mathrm{~g}$ body weight), instead of glucose, was injected into the right jugular vein immediately after the withdrawal of the control blood sample. from the weight of food remaining in the hopper. These figures gave only a crude measure of the relative amounts of food consumed at different times of the day, but they also provided some idea of the activity of the animals.

\section{Results}

The figures derived from the glucose tolerance test of fasted animals are presented in Table 1 . There was no significant variation between the mean fasting 
blood sugar levels taken at different times of the day $(P$ always $>0.05)$. There was also no significant variation in the mean response to a glucose load $(P$ always $>0.1$ ).

The figures from the assay of glucose tolerance in fed mice are also presented in Table 1. The mean pre-glucose blood sugar level did not vary significantly throughout the day, with the exception of the $13.00 \mathrm{~h}$ group whose mean was significantly higher than the others [08.00 h $(P<0.05) ; 20.00 \mathrm{~h}(P<0.01) ; 01.00 \mathrm{~h}$ $(P<0.01)]$. Also, so far as the response to a glucose load was concerned only the $01.00 \mathrm{~h}$ group showed a significantly different (i.e. greater) tolerance to glucose than the other three groups [08.00 h $(P<0.01)$; $13.00 \mathrm{~h}(P<0.01) ; 20.00 \mathrm{~h}(P<0.01)]$.

The mean difference between control and glucose loaded animals was $96 \pm 3.2 \mathrm{mg} \%$ in the fed groups and $115 \pm 3.1 \mathrm{mg} \%$ in the fasted groups, which indicates a significantly greater glucose tolerance in the fed animals.

The effects of the stress of disturbance and handling of the experimental mice, upon the blood sugar, are shown in Fig. 1 (each point represents 4 animals). In the fasted groups, mice from which samples were taken, approximately $40 \mathrm{~min}$ after the start of the experiment (mice 5 and 6) had higher blood sugar levels before sugar loading than mice 1 and $2(P<0.001)$ and mice 8 and $9(P<0.001)$. Also the blood of mice 5 and 6 showed a significantly smaller return to normal, after sugar loading, than mice 1 and $2(P<0.01)$ and mice 8 and $9(P<0.05)$.

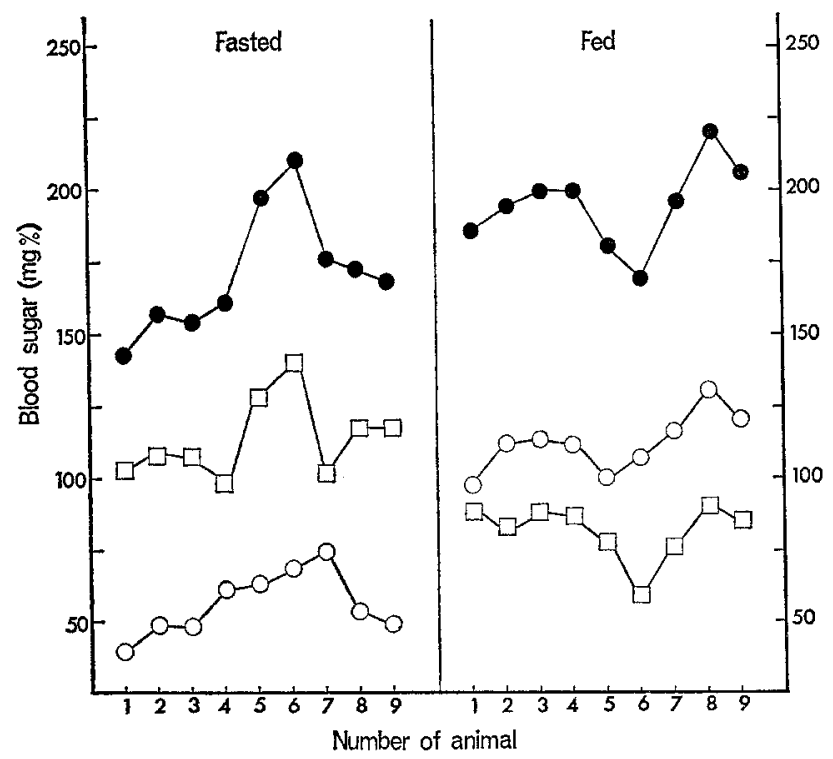

Fig. 1. Sequential blood sugar levels of mice subjected to glucose tolerance tests

Each point represents a mean of the values from 4 mice $(08.00 \mathrm{~h}, 13.00 \mathrm{~h}, 20.00 \mathrm{~h} \& 01.00 \mathrm{~h})$

Control

$10 \mathrm{~min}$ post-glucose

Net $10 \mathrm{~min}$ increase
In the fed animals the double peak was not a significant one though the 6 th animals to receive a glucose load showed a greater return of blood sugar to control levels than all the other animals combined $(P<0.05)$.

Insulin sensitivity figures are presented in Table 2. The $20.00 \mathrm{~h}$ group showed a significantly smaller actual fall in blood sugar than the 08.00 and the $13.00 \mathrm{~h}$ groups $(P<0.01$ in each case). The $01.00 \mathrm{~h}$ group fell between the 20.00 and the $08.00 \mathrm{~h}$ groups and the actual fall was not significantly different from either of them $(P>0.2$ in both cases). When expressed as percentages of control sugar levels, the difference between the $20.00 \mathrm{~h}$ group and the $08.00 \mathrm{~h}$ group was significant $(P<0.05)$, but other differences did not reach significance level.

The concentrations of liver glycogen are shown in Table 3. A circadian rhythm of deposition and release of glycogen clearly shows a minimum concentration at $01.00 \mathrm{~h}$. Differences between successive readings are all significant to the 0.01 level with the exception of that between the 20.00 and the $01.00 \mathrm{~h}$ groups $(P<$ $1.0>0.05)$.

Table 3. The daily cycle of liver glycogen concentration

\begin{tabular}{lcl}
\hline Time of assay & $\begin{array}{l}\text { No of } \\
\text { Mice }\end{array}$ & $\begin{array}{l}\text { Glycogen } \\
\mathrm{mg} / 100 \mathrm{~g}\end{array}$ \\
\hline $08.00-09.00$ & 9 & $2.09 \pm 0.08^{\mathrm{a}}$ \\
$13.00-14.00$ & 10 & $1.10 \pm 0.10$ \\
$16.00-17.00$ & 9 & $1.77 \pm 0.16$ \\
$20.00-21.00$ & 9 & $2.98 \pm 0.29$ \\
$01.00-02.00$ & 8 & $3.77 \pm 0.27$ \\
\hline
\end{tabular}

a S.E.

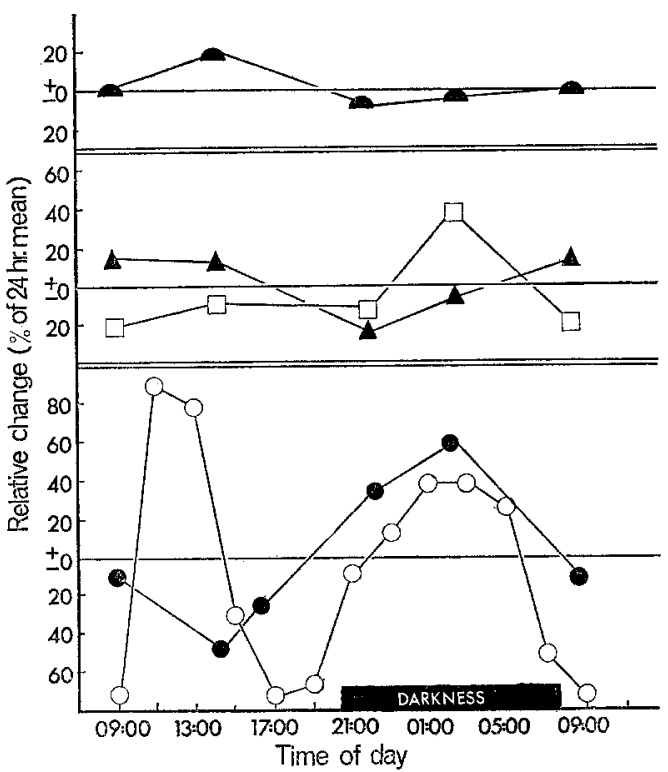

Fig. 2. Results presented as a percentage of the $24 \mathrm{~h}$ mean

- Fed blood sugar level

$\square$ Glucose tolerance of fed animals

Insulin sensitivity of fed animals

Liver glycogen

Food taken 
Fig. 2 presents the results as percentages of their $24 \mathrm{~h}$ means. Included are the relative figures for food consumed, which show two peaks, at approximately mid-day and mid-night. These peaks corresponded to observed increases in activity of the animals.

\section{Discussion}

The absence of any variation in the basal levels of blood sugar or tolerance to a glucose load in animals which had been fasted for $24 \mathrm{~h}$ as compared with others which had been fed ad libitum suggests that food intake must induce hormonal responses, under the present conditions, which do not permit the maintenance of a constant level of blood sugar. The peak of feeding activity which occurred in the middle of the dark period would be regarded as a normal one for nocturnal animals, but somewhat higher rates of feeding activity were recorded for the briefer period $11.00-13.00 \mathrm{~h}$ after which the animals ceased feeding and rested before the night activity started at about $20.00 \mathrm{~h}$. It is possible that the morning activity was related to disturbance of the colony in the early part of the light period and it is significant that the double peak of feeding activity corresponds in time with the double peak of $\beta$-cell stimulation recorded by Hellman \& Hellerstrom [7]. As might be expected the fed animals, as compared with the fasted ones, had higher blood sugar levels throughout the day and showed a higher tolerance to a glucose load. Thus, the increased insulin made available in response to feeding, although not maintaining a blood sugar level as low as that of the fasting animals, must be greater than in the fasting animals [11]. The high levels of blood sugar recorded in the fed animals in the morning, as compared with other times of the day, might well have been due to the fact that these animals were feeding at a time when liver glycogen release was at its maximum.

The high glucose tolerance of fed animals which occurred at $01.00 \mathrm{~h}$ might also be related to the liver glycogen cycle. It has long been known that the liver undergoes a circadian cycle of glycogen storage and release, and the present results agree with the findings of Agren et al. [1] in rats and mice and Barnum et al. [2] in mice. In the present experiments maximum concentrations of liver glycogen occurred in the middle of the dark period, and corresponded in time with the period of maximum feeding activity and also with the large increase in glucose tolerance. It would be reasonable to suppose that the increased tolerance to glucose at this time resulted from the coincidence of a high assimilation of carbohydrate and a high insulin activity, together with an increasing sensitivity to insulin.

Changes in insulin sensitivity do not appear to be directly related to changes in glucose tolerance. The fall in sensitivity which occurred between 13.00 and $20.00 \mathrm{~h}$, and which coincided with the period of comparative rest when the animals were not feeding, corresponded in time with the steep rise in glycogen assimilation, so that these two factors are inversely related. A tendency to return to high sensitivity occurred as liver glycogen reached its peak, and this trend was completed during the period of high body activity when sugar utilization would necessarily be high. It would appear that the insulin sensitivity curve does not follow either the feeding activity curve reported here or the pattern of diurnal changes in the ratio of $\beta / \alpha$-cell activity reported by Hellman \& Hellerstrom [7]. Both $\beta$-cell activity as recorded by them and insulin sensivity recorded here were at a minimum at $20.00 \mathrm{~h}$ immediately following the period of least feeding activity which occurred in the afternoon. However, no second fall in insulin sensitivity to correspond with the early morning fall in bodily activity or Hellman and Hellerström's fall in $\beta$-cell activity was recorded.

A relationship between the present data can be presented which is based on the assumption that the cycle of liver glycogen release and deposition is a basic one, closely related to, though not necessarily influenced directly by, the circadian cycle of adrenocortical activity $[9,6]$ and affecting other parameters as a result of its more direct effect on the carbohydrate balance of the body. The deposition of glycogen in the first half of the night would create, then, a negative carbohydrate balance in the blood, and coupled with the fact that the animals were resting and not feeding at the time, this might well account for the low insulin activity reported by Hellman \& Hellerstrom [7] and for the loss of insulin sensitivity reported here. The attainment of maximum glycogen deposition, in the middle of the dark period, might, in turn, have initiated the feeding activity which would necessitate an increase in insulin activity. The coincidence of maximum glycogen deposition and high insulin activity, it is suggested, is responsible for the high glucose tolerance at this time.

The liver glycogen release phase occurs after midnight and would tend to create a positive carbohydrate balance in the blood. This would result in the sharp fall in feeding activity (and in $\beta$-cell activity recorded by Hellman \& Hellerstrom [7]) and therefore in glucose tolerance. The insulin sensitivity, however, shows a rise above the $24 \mathrm{~h}$ mean level, a finding in favour of the suggestion that this sensitivity is related directly to liver glycogen deposition and release.

It is suggested that the variations in blood sugar throughout the glucose tolerance tests are due to the release of epinephrine and/or corticosterone resulting from the disturbance of the animals, so that the hyperglycaemic and insulin-antagonising effects of either or both of these hormones became maximal $40 \mathrm{~min}$ after the start of the experiment. Reference to this effect was made by Barrett \& Stockholme [3] who reported a lower blood corticosterone level in the first animal removed from a cage than in succeeding ones. 
The double peak found in the fed animals, it is suggested, is due to a different balance of epinephrine/ insulin necessary to maintain normoglycaemia before sugar loads were administered. In between the two peaks and in contrast with the corresponding fasted animals, the high tolerance to glucose is indicative of a relative absence of insulin antagonism at this time.

Further work is necessary in order to establish the relative significance of epinephrine and corticosterone, so far as their effects upon blood sugar are concerned, under the present kind of experimental conditions.

\section{References}

1. Agren, G., Wilander, O., Jorpes, E.: Cyclic changes in the glycogen content of the liver and the muscles of rats and mice. Their bearing upon the sensitivity of the animals to insulin and their influence on the urinary output of nitrogen. Biochem. J. 25, 777-785 (1931).

2. Barnum, C.P., Jardentzky, C.D., Halberg, F.: Time relations among metabolic and morphologic 24-hour changes in mouse liver. Amer. J. Physiol. 195, 301310 (1958).

3. Barrett, A.M., Stockham, M.A.: The effect of housing conditions and simple experimental procedures upon the corticosterone level in the plasma of rats. J. Endocr. 26, 97-105 (1963)
4. Guillemin, R., Dear, W.E., Liebilt, R.A.: Nychthemeral variations in plasma free corticosteroid levels of the rat. Proc. Soc. exp. Biol. 101, 394-395 (1959).

5. Halberg, F., Barnum, C. P., Silber, R.H., Bittner, J. J.: 24-hour rhythms at several levels of integration in mice on different levels of light regimens. Proc. Soc. exp. Biol. 97, 897-900 (1958).

6. - Halberg, E., Barnum, C.P., Bittner, J.J.: Photoperiodism and related phenomena in plants and animals. Withrow ed. (AAAS 1959).

7. Hellman, B. O., Hellerström, C.: Diurnal changes in the function of the pancreatic islets of rats as indicated by nuclear size in the islet cells. Acta. endocr. 31, $267-281(1959)$.

8. Howland, R.J., Nowell, N.W.: In press.

9. Martorano, J.J.: Variation in liver glycogen levels of intact and adrenal-ectomized mice. Naval Med. Res. Inst. Res. Rept. 15, 191-198 (1957).

10. Nowell, N.W., Howland, R.J.: The control of blood sugar in the laboratory rat and golden hamster I. Intravenous glucose tolerance and insulin sensitivity tests. Acta. endocr. 52, 149-153 (1966).

11. Randle, P.J., Garland, P.B., Hales, C.N., Newsholme, E.A.: The glucose fatty acid cycle and Diabetes Mellitus. Ciba Foundation Colloquia Endocrin. 15, 192-212 (1964).

Dr. N.W. Nowell

University of Hull

Dept. of Zoology

Yorkshire, England 